\begin{tabular}{|c|c|c|}
\hline$\exists$ & $\begin{array}{c}\text { International Journal of Current Research } \\
\text { and Academic Review }\end{array}$ & 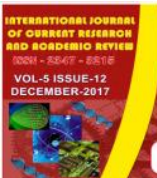 \\
\hline $\begin{array}{l}\text { EXCELLENT } \\
\text { PUBLISHERS } \\
\end{array}$ & 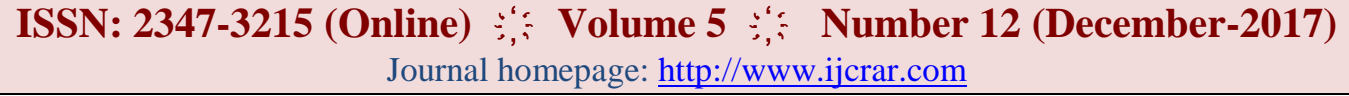 & \\
\hline
\end{tabular}

doi: https://doi.org/10.20546/ijcrar.2017.512.008

\title{
Characterization and Aquifer Functioning System of Haraz Al Biar (North Chari Baguirmi)
}

\author{
A. Mahamat Nour ${ }^{1,2 *}$, H. Abderamane ${ }^{1}$, B. Ngounou Ngatcha $^{3}$, P. Deschamps ${ }^{2}$ and Bouchezc ${ }^{2}$ \\ ${ }^{1}$ University of N'Djamena - Department of Geology, N'Djamena, Chad \\ ${ }^{2}$ Aix Marseille University, CNRS, IRD, College of France, UMR-CEREGE, Mediterranean Technopole of Arbois, \\ Aix-en-Provence, France \\ ${ }^{3}$ University of Ngaoundere, Faculty of Sciences, Ngaoundéré, Cameroon
}

*Corresponding author

\begin{abstract}
Haraz Al Biar (Northern Chari-Baguirmi) is located in the semi-arid zone, limited to the north by Lake Chad and on the west by Chari - Logone. The study of Haraz Al Biar aquifer system aims to improve its knowledge for the sustainable management of groundwater resources. In the study area, water sampling campaigns were realized. These samples have been the subject of the study of hydrodynamic and hydrochemical parameters of the aquifer system. The piezometric data show that the transfer of water from Lake Chad is hydraulically possible because the level of the lake is above the static level of the water table. The chemical data allowed to distinguish the difference between bicarbonate and sulphate facies.
\end{abstract}

\section{Article Info}

Accepted: 30 November 2017

Available Online: 20 December 2017

\section{Keywords}

Haraz al Bar,

Lake Chad Basin,

Hydrochemistry,

Hydrodynamical,

Depression

\section{Introduction}

The surface waters are scarce or absent in arid and semiarid area (Joly, 2006; SFDI, 2011), groundwater often makes up the essential to the mobilization of water resources or the ones likely to be (SFDI, 2011; Bensaâd, 2011; Merem-Farah, 2017). The groundwater is part of a category of difficult resources to grasp. It typically falls under the environmental goods and seem to belong to everyone, at the same time they do not belong to no one (Olivier, 2004). The Sahelian areas suffer from a strong environmental degradation due to climate change manifested by the decline and the randomness of rainfall (Kawtar, 2004, Ndiaye and Ndiaye, 2013). The population of these areas feeds almost themselves exclusively on groundwater through wells and / or boreholes. These boreholes and wells are very variable in their depth and the quality of water from one point to another. Pressures on groundwater are more and more increasingly important due to changes in consumption patterns (Margat, et al., 2008), the increase in world population and the corresponding needs (agriculture, drinking water, industry, energy, etc.).Their impact can be very harmful (lowering of groundwater level, impaired water quality, land subsidence, saltwater intrusion, pollution, loss of biodiversity, etc.) in the short, medium or long term and irreversible or with significant restoration costs (Sylvie, 2001; Olivier, 2004). Good management, protection of water resources and study of aquifers are a priority.

The Chari Baguirmi, like the other regions of the Sahel, has known in the last decades and continues to suffer from a strong environmental degradation due to the 
climate contrasts affecting the Lake Chad basin. The scarcity of rainfall has led to the decrease level of Lake Chad water. This drop in water level has caused the drying up of some streams. This phenomenon is aggravated by the advance of the desert and the setting up of sands. These conditions have forced the people leading a farming activity transhumance who make use of groundwater through traditional wells and boreholes their daily needs.

Lack of surveillance network in Chari - Baguirmi in general and Haraz Al Biar in particular is a major problem to characterize precisely the hydrodynamic and hydro-chemical functioning of this sheet.

In this sector, the studies carried out by Schneider and Bonnet, 1968; BRGM, 1987; Schneider and Wolff, 1992; Daira, 2000; Abderamane, 2012 and Bouchez, 2015 have set surface water links (Logone-Chari system and Lake Chad) with the aquifer of the Quaternary. The groundwater levels are lower along Chari and Logone increasingly deep as one gets to be distant from ChariLogone (Daira, 2000; Abderamane, 2012). To date, few studies have been conducted in order to make clear the relationship between the sheet of Haraz Al Biar and surface water on one hand; to characterize the hydrodynamic and hydrochemical functioning on the other hand.

\section{Natural Framework}

\section{Location of the study area}

The Lake Chad basin is located in Central Africa between $6^{\circ}$ and $24^{\circ}$ North latitude and $8^{\circ}$ and $24^{\circ}$ East longitude. It occupies an area of about 2.5 million square $\mathrm{km}$ or $8 \%$ of the area of Africa. It is bordered by the relief of Adamawa south, the Tibesti in the north of Ouaddai in the east of Jos in the southwest and Hoggar in the northwest (Figure 1). The study area is restricted to Haraz Al Biar region (Massaguet - Djermaya - ManiTourba) and is located in the northern part of Chari Baguirmi. It stretches between $12.06^{\circ}$ and $13.20^{\circ}$ north latitude and between $14.50^{\circ}$ and $15.90^{\circ}$ East.This area is characterized by natural sets consisting of Chari-Logone deltas, flood zones and dune ridges.

\section{Geology, hydrogeology and vegetation}

The geology of Chad basin was widely studied by Louis (1970). There are two major geological units (Figure 1): (1) to the south and north-northeast, outcrop formations of the Precambrian basement. This base consists essentially of granites, migmatites, quartzites, gneiss, charnockites, amphibolite, mica schists and (Gac, 1980); (2) in the center and north-west, series of coverings of tertiary-age sandstone sediments and late Quaternary fluvial or fluvial-lacustrine of current Quaternary.

The Quaternary formations are characterized by alternations of deposits between wet and dry poles (Schneider and Wolff, 1992).

More locally (study area), there are two rhyolitic massifs (Hadjer El Hamis and Hadjer Bigli).They gathered at Maastrichtian K/Ar $68.9 \pm 1.4$ My was determined at Hadjer Bigli (Schroeter and Gear,1973). Granite points could be even more recent, tertiary, if one accepts an analogy with the data of North Cameroon. The oldest formations probably correspond to the Pan-African.

Much of the soil Haraz Al Biar area was formed on fluviolacustrine alluvial deposits of the Chad basin (Pias, 1964; Pias, 1968; Cesar, 1990). There is a quaternary clay lake series and a sub-current to present alluvial series partially superimposed on the previous one (Pias, 1970). According to these authors, these formations gave rise to two major types of soils (1) vertisols resting on a dark clay, tropical, occupying the lacustrine areas; (2) pseudo Gley soils with stains and concretions whose texture is sandy-loamy. These were formed from recent alluvium.

The description of the hydrogeological framework is essentially based on that of the Tertiary and Quaternary geological formations. The aquifer Pliocene essentially consists of an alternation of sand and clay beds 5 to $10 \mathrm{~m}$ in thickness to a maximum total thickness of $120 \mathrm{~m}$ (Schneider, 2001). On the scale of the Chad basin, the flow is from south to north-east of Chad where groundwater is artesian (Schneider, 2001). Continental Terminal is mostly the sandstone or sand alternating with clays and sometimes conglomerates (Bouchez, 2015). The Quaternary aquifer is characterized by a general water table. This layer consists of aeolian sands and fluviolacustres series (Djoret, 2000; Massuel, 2001; Abderamane et al., 2012).

The vegetation in Haraz Albiar sector (North Chari Baguirmi) is composed of a Sahelian plant formation which consists of two elements (1) a herbaceous layer, consisting mainly of grass-dominated annuals; (2) a stand of woody plants (trees and shrubs) dominated mainly by thorny trees. 


\section{Hydro-climatic Description}

The climate of the study area is semi-arid tropical type. Rainfall is marked by a strong irregularity in its spatial and temporal distribution. This irregularity is explained by the importance of the distribution of the flow of the Guinean monsoon, the main source of moisture. It is marked by a long dry season from October to May and a short rainy season ranging from June to September. The average interannual rainfall is $535 \mathrm{~mm}$ in Chari Baguirmi between 1982 and 2011, mean interannual temperatures oscillate between $26^{\circ} \mathrm{C}$ and $28^{\circ} \mathrm{C}$. During the hot season, average monthly temperatures range from $33^{\circ} \mathrm{C}$ to $40{ }^{\circ} \mathrm{C}$. The value of evaporation is about the order of 2500 mm.year $^{-1}$ cumulative annual average in N'Djamena station for the period 1982-2011. This value, several times higher than the annual rainfall, thus leading role in the water balance.

The river system is dominated by the Logone - Chari and Lake Chad system (Figure 1). They are functional the whole year. Chari-Logone regime is characterized by a flood that begins with the start of the rainy season (MayJune).Not important during this first phase, it peaks in October (Figure 2).The recession is regular from the end of October. Low water lasts from December to June.

\section{Materials and Methods}

\section{Measure of dynamic level}

The term dynamic level is used because the majority of the structures in which we performed the measurements were subject to solicitations. We measured the dynamic levels with potentiometric sensor. The potentiometric sensor works very simply. By manual unwinding of the roll; we come down the end of the wire equipped with the electrode which in contact with the water in the well is felt by a ring whose device is placed at the central axis of the roller. The reading of the dynamic level is done immediately by a simple reading of the graduations in decameters already existing over the whole length of the wire in roll. Thus we have dynamic levels of 14 wells. The measurement of the piezometric level is calculated by difference between the side of the ground (reference the work) and the depth of water.

\section{Measurement of physicochemical parameters}

Measurements of the electrical conductivity, temperature and $\mathrm{pH}$ of the 14 wells were carried out and in nonfiltered samples (in a bucket) with a conductivity and $\mathrm{pH}$ meter. Uncertainties about $\mathrm{pH}$ measurements are 0.1 unit on the electric conductivity of $10 \mathrm{microsiemens} / \mathrm{cm}$ and the temperature of $0.5^{\circ} \mathrm{C}$.

\section{Sampling of water for major chemical elements}

Sampling is essential because it determines the relevance of the analysis. It must be of quality but also representative of what one wants to analyze.

The observation network has a total of 11Wells and observation points were selected to show the chemical evolution of the water in the aquifer.

For large items, samples were taken in polyethylene bottles, material releasing only very little soluble elements and therefore do not alter the chinomic composition of stored sample were taken two vials of $30 \mathrm{ml}$ of filtered water 0,45 membrane. The sample for cation analysis is immediately acidified to avoid precipitation of carbonates.

Chemical analyzes of the waters of the table cloths were conducted in Germany by the laboratory reference: official laboratory Groundwater Resources / Groundwater Dynamics of the Federal Institute for Geoscience and Natural Resources GEOZENTRUM HANNOVER Stilleweg 2 30655hannover).

The major chemical components of the Lake Chad waters are provided by Camille CEREGE in France.

\section{Reference piezometric map}

The realization of a spatial map by the method of kriging and interpolation require a fairly good distribution of measurement points. Poor (or less) data distribution can provide extrapolated data. We have very little data on the piezometric levels of the study area.

With these data we, cannot realize a piezometric map with good accuracy and appropriateness. So we use in discussing the piezometric map Chari Baguirmi conducted by Abderamane (2012) as a reference map (Figure 3).

The piezometric map carried out the high water period by Abderamane (figure3) shows the feeding zones of Chari Baguirmi aquifer. This feeding zone is located in the West, which is Chari-Logone and Lake Chad. The general flow of the sector is from the South and North to the center of the depression of Chari Baguirmi. 


\section{Results and Discussion}

\section{Piezometric levels of Haraz Al Biar}

The sampling campaign was carried out during the high water period. The piezometric levels are between 252 and $272 \mathrm{~m}$ (Table 1). The hydraulic gradient between Mani and Bachome is very low (0.0037\%).

\section{Physico-chemical parameters of groundwater}

When sampling in situ the measured physico-chemical parameters are the temperatures, the hydrogen potential $(\mathrm{pH})$ and the electrical conductivity are recorded in Table 1. The average groundwater temperature is $28.91{ }^{\circ} \mathrm{C}$. It ranges from $27{ }^{\circ} \mathrm{C}$ in Massakori to $31.4{ }^{\circ} \mathrm{C}$ in Bir Barka and Naala. The $\mathrm{pH}$ is a physicochemical parameter that varies greatly. Values range from 6.88 to 8.10 . The highest $\mathrm{pH}$ is observed in Massakory. Measurements of conductivities are heterogeneous, the lowest measured in Mani $\left(270 \mu \mathrm{s} . \mathrm{cm}^{-1}\right)$ near Chari-Logone River. The highest conductivity is measured next to Batchome $\left(2620 \mu \mathrm{s} . \mathrm{cm}^{-1}\right)$.

\section{Major chemical elements of groundwater}

\section{Major chemical elements}

For major elements, chemical analysis is considered valid when the ion balance $[(\Sigma$ cations $-\Sigma$ anions $) /(\Sigma$ cations $+\Sigma$ anions)] does not exceed $\pm 5 \%$. For more than $72 \%$ of these analyzes, this condition is verified (Table 2 ). An error in ionic balance has been noted, particularly for certain wells. In the case of this study the samples of Bir Barka; Djermaya and Guirbé are not balanced. This error on the ionic balance could come from an analytical error (results of the invalid analyzes) or from a particular mineralization (important presence in the water of ions which were not analyzed).

The analysis of the concentrations of the chemical elements shows a great variation from one sample to another. The sodium concentrations range from 0.4 to 15 $\mathrm{meq} / \mathrm{L}$ (Mani to Bir Barka), the potassium from 0.1 $\mathrm{meq} / \mathrm{L}$ (Mani) to $1.3 \mathrm{meq} / \mathrm{L}$ (Djarmaya) while, the calcium levels and magnesium range respectively from $1.1 \mathrm{meq} / \mathrm{L}$ (Tourba) to $5 \mathrm{meq} / 1$ (Djermaya) and from $0.67 \mathrm{meq} / \mathrm{L}$ (Naala) to $3 \mathrm{meq} / \mathrm{L}$ (Tourba). The concentrations of chlorides and sulphates range from 0.1 (Mani) to $1.30 \mathrm{meq} / \mathrm{L}$ (Bir Barka), and from 0.0 (Mani) to 9 meq / 1 (Bir Barka), respectively. Bicarbonates range from $2 \mathrm{meq} / \mathrm{L}$ (Naala) to $24 \mathrm{meq} / \mathrm{L}$ (Guirbé).
For all the analyzes, the dominant anion is bicarbonate with an average content of 8.36 meq. $1^{-1}$ except Tourba. The sulfate ion is in second position with a value of 3 times lower with 2.69 meq. $1^{-1}$ The levels of chlorides and nitrates are far behind with respectively 0.89 and 0.18 meq. $1^{-1}$ For cations, sodium dominates for some samples with a mean value of 6.92 meq. $\mathrm{l}^{-1}$, followed by the calcium with 2,6 meq. $1^{-1}$ Finally the magnesium and potassium levels are much lower with respective values of 1.43 and 0.55 meq..$^{-1}$ In general, concentrations of major ions follow the following sequence: $\mathrm{Na}^{+}>\mathrm{Ca}^{2+}>$ $\mathrm{K}^{+}>\mathrm{Mg}^{2+}$ Cation, $\mathrm{HCO}_{3}^{-}>\mathrm{SO}_{4}{ }^{2-}>\mathrm{Cl}^{-}>\mathrm{NO}_{3}^{-}$in the anions.

\section{Piper diagram}

The chemical data allowed through the piper diagram to characterize the chemical facies. The aquifer of Haraz $\mathrm{Al}$ Biar presents a great variability of facies. A more or less magnesian calcium bicarbonate facies present in the wells (Afrouk, Boutelfil, Djermaya, Mani and Naala); facies sodium bicarbonate potassium present in the wells (Bir Barka Dibindi, Gomboya, Guirbé) and a facies sodium sulfate present in Tourba (Figure 3). The lake waters have a single type of facies (Figure 3); a calcium bicarbonate facies.

\section{Spatial distribution of the chlorides and sulfates $\left(\mathrm{SO}_{4}{ }^{2-}\right)$}

The distribution of chloride content in groundwater has been analyzed. Chloride levels in groundwater in the study area vary widely from $4.5 \mathrm{mg} / \mathrm{L}$ to $154 \mathrm{mg} / \mathrm{L}$. The lowest grades are near Chari-Logone in Mani. The highest grades are at the edge of Lake Chad in Ganatir. The figure 4 shows a very clear spatial distribution of chloride contents.

The spatial distribution of the contents of $\mathrm{SO}_{4}{ }^{2-}$ is very heterogeneous (Figure 4). It closely follows the evolution of the total mineralization of the waters. The lowest levels $\left(0.5 \mathrm{mg} \mathrm{L}^{-1)}\right.$ are observed to Mani on the edge of Chari-Logone. The highest levels are recorded on the edge of Lake Chad (with an average value of $241 \mathrm{mg} \mathrm{L}^{-}$ $\left.{ }^{1}\right)$.They reach $363 \mathrm{mg} / \mathrm{L}$ to Tourba and $859 \mathrm{mg} . \mathrm{L}^{-1}$ Ganatir.

\section{Hydrodynamic}

The hydrodynamics and piezometry aquifer of Quaternary Lake Chad Basin have been studied since the 70 s by the Commission of the Lake Chad Basin (LCBC) and updated by (Eberschweiler 1996). 
Table.1 Piezometric and physicochemical data

\begin{tabular}{|c|c|c|c|c|c|c|c|c|}
\hline Noms & Longitude & Latitude & Altitude(m) & $\begin{array}{c}\text { Niveau } \\
\text { dynamique (m) }\end{array}$ & $\begin{array}{c}\text { Niveau } \\
\text { piézométrique (m) }\end{array}$ & $\begin{array}{c}\text { Température } \\
\text { en }{ }^{\circ} \mathrm{C}\end{array}$ & $\mathrm{pH}$ & $\begin{array}{c}\text { Conductivité } \\
\text { électrique en } \mu \mathrm{S} / \mathrm{cm}\end{array}$ \\
\hline AFROUK & 509050,991 & 1354436,31 & 290 & 22,00 & 268,00 & 27,2 & 7,12 & 437 \\
\hline BATCHOME & 572100,96 & 1421734,5 & 284 & 30,00 & 254,00 & 29,9 & 7,31 & 2620 \\
\hline BIR BARKA & 560873,888 & 1403399,04 & 288 & 32,00 & 256,00 & 31,4 & 7,29 & 1994 \\
\hline BOUTEL FIL & $15^{\circ} 34^{\prime} 49,8^{\prime \prime}$ & $12^{\circ} 56^{\prime} 52,8^{\prime \prime}$ & 288 & 25,24 & 262,76 & 27,6 & 7,35 & 715 \\
\hline DIBINDI ALAY & 513387,985 & 1383250,55 & 284 & 25,00 & 259,00 & 27,6 & 7,12 & 328 \\
\hline DJERMAYA & 505440,717 & 1371424,91 & 292 & 28,00 & 264,00 & 28,5 & 6,89 & 1369 \\
\hline GANATIR NOL & 518394,203 & 1416913,83 & 284 & 26,00 & 258,00 & 28,7 & 7,17 & 444 \\
\hline GOMBOYA & 518127,256 & 1400759,1 & 289 & 31,70 & 257,30 & 29,0 & 6,95 & 1349 \\
\hline GUIRBE & 470543,969 & 1418142,79 & 291 & 21,75 & 269,25 & 29,2 & 8,10 & 2440 \\
\hline MANI CL & 466110,191 & 1408428,52 & 280 & 8,00 & 272,00 & 28,1 & 7,28 & 270 \\
\hline MASSAKORI & 580189,793 & 1437802,04 & 287 & 31,30 & 255,70 & 30,0 & 7,64 & 1958 \\
\hline NAALA & $15^{\circ} 15^{\prime} 35,4^{\prime \prime}$ & $12^{\circ} 27^{\prime} 59,4^{\prime \prime}$ & 292 & 32,00 & 260,00 & 31,4 & 6,88 & 836 \\
\hline SALGA & 502986,253 & 1398508,01 & 288 & 29,50 & 258,50 & 30,7 & 7,83 & 1688 \\
\hline TOURBA & 531641,937 & 1423029,41 & 277 & 18,00 & 259,00 & 27,6 & 7,36 & 1596 \\
\hline
\end{tabular}

Table.2 Elementary Chemistry

\begin{tabular}{|c|c|c|c|c|c|c|c|c|c|c|c|}
\hline \multirow{2}{*}{ villages } & \multicolumn{5}{|c|}{ Cations en meq/L } & \multicolumn{5}{|c|}{ Anions en meq/L } & \multirow{2}{*}{ Balance ionique } \\
\hline & $\mathrm{K}^{+}$ & $\mathrm{Na}^{+}$ & $\mathrm{Mg}^{2+}$ & $\mathrm{Ca}^{2+}$ & $\sum$ Ccations & $\mathrm{SO}_{4}{ }^{2-}$ & $\mathrm{HCO}_{3}{ }^{2-}$ & $\mathrm{NO}_{3}^{-}$ & $\mathrm{Cl}^{-}$ & $\sum$ Canions & \\
\hline Afrouk & 0,50 & 0,60 & 0,75 & 2,60 & 4,45 & 0,17 & 3,00 & 0,30 & 0,12 & 3,59 & 10,70 \\
\hline Birbarka & 0,40 & 15,00 & 2,40 & 4,70 & 22,50 & 9,00 & 13,00 & 0,01 & 1,30 & 23,31 & $-1,77$ \\
\hline Boutelfil & 0,50 & 1,60 & 1,50 & 4,00 & 7,60 & 0,30 & 6,00 & 0,60 & 0,40 & 7,30 & 2,01 \\
\hline Dibindi A & 0,20 & 1,70 & 0,44 & 1,20 & 3,54 & 0,20 & 3,00 & 0,06 & 0,07 & 3,33 & 3,06 \\
\hline Djermaya & 1,30 & 3,50 & 2,10 & 5,00 & 11,90 & 0,02 & 12,00 & 0,01 & 1,90 & 13,93 & $-7,86$ \\
\hline Gomboya & 0,40 & 10,00 & 1,40 & 2,90 & 14,70 & 3,00 & 11,00 & 0,20 & 0,60 & 14,80 & $-0,34$ \\
\hline Guirbé & 1,60 & 19,30 & 1,50 & 1,30 & 23,70 & 3,00 & 24,00 & 0,00 & 1,80 & 28,80 & $-9,71$ \\
\hline Mani & 0,10 & 0,40 & 0,78 & 1,60 & 2,88 & 0,00 & 3,00 & 0,10 & 0,10 & 3,20 & $-5,26$ \\
\hline Naala & 0,10 & 0,60 & 0,67 & 1,60 & 2,97 & 0,30 & 2,00 & 0,60 & 0,30 & 3,20 & $-3,73$ \\
\hline Salga & 0,40 & 13,50 & 1,20 & 2,60 & 17,70 & 5,70 & 10,00 & 0,10 & 2,10 & 17,90 & $-0,56$ \\
\hline Tourba & 0,60 & 10,00 & 3,00 & 1,10 & 14,70 & 8,00 & 5,00 & 0,01 & 1,10 & 14,11 & 2,05 \\
\hline Lac 1 & 0,05 & 0,15 & 0,16 & 0,25 & 0,61 & 0,00 & 0,65 & & $0,00^{\top}$ & 0,65 & $-2,99$ \\
\hline Lac 3 & 0,06 & 0,16 & 0,16 & 0,26 & 0,64 & 0,01 & 0,58 & & $0,01^{\top}$ & 0,60 & 2,59 \\
\hline Lac 10 & 0,06 & 0,15 & 0,16 & 0,26 & 0,62 & 0,00 & 0,65 & & $0,00^{\top}$ & 0,66 & $-2,99$ \\
\hline Lac 14 & 0,06 & 0,15 & 0,17 & 0,28 & 0,66 & 0,00 & 0,69 & & $0,01^{\top}$ & 0,70 & $-2,57$ \\
\hline Lac 17 & 0,06 & 0,15 & 0,18 & 0,29 & 0,68 & 0,00 & 0,67 & & $0,00^{\boldsymbol{r}}$ & 0,68 & 0,14 \\
\hline Lac 19 & 0,06 & 0,15 & 0,15 & 0,25 & 0,61 & 0,00 & 0,63 & & $0,00^{\top}$ & 0,63 & $-2,15$ \\
\hline Lac 24 & 0,06 & 0,16 & 0,16 & 0,26 & 0,63 & 0,00 & 0,58 & & $0,01^{\top}$ & 0,59 & 3,68 \\
\hline Lac 27 & 0,06 & 0,15 & 0,17 & 0,27 & 0,65 & 0,00 & 0,59 & & $0,00^{\top}$ & 0,60 & 3,72 \\
\hline Lac 32 & 0,06 & 0,15 & 0,16 & 0,27 & 0,65 & 0,00 & 0,58 & & $0,01^{\top}$ & 0,59 & 4,13 \\
\hline
\end{tabular}


Fig.1 Geological map of the Chadian basin (Louise, 1970), discontinuous black line (delineation of the Lake Chad basin thanks to the DEM, SRTM topo 30 data), the continuous brown line (Mega lake Chad, delimited by the SIEREM), blue features (streams), discontinuous red line study area (Haraz Al Biar)

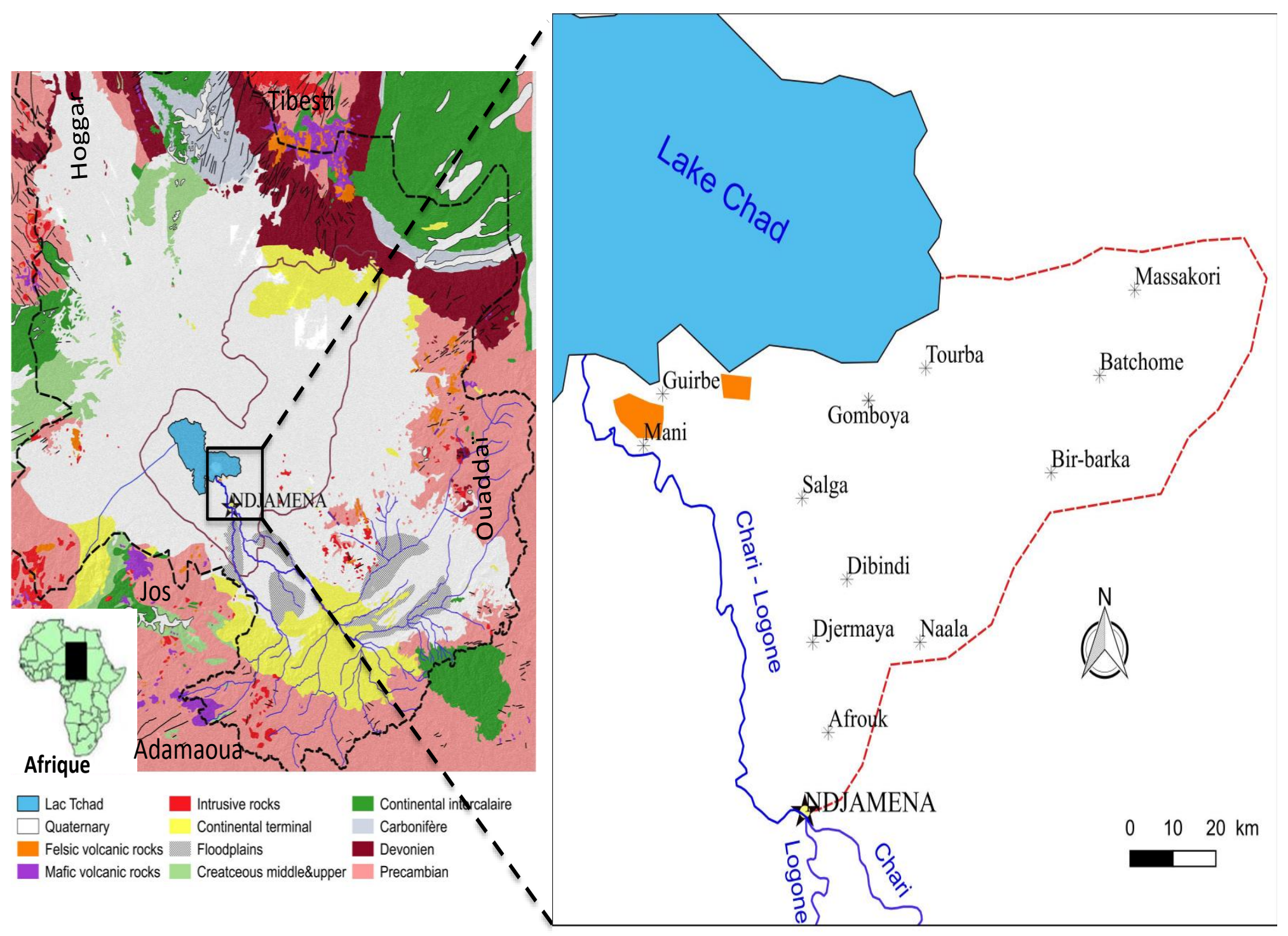


Fig.2 Piezometric map of Chari-Baguirmi during the high-water period (December 2008) by Abderamane (2012)

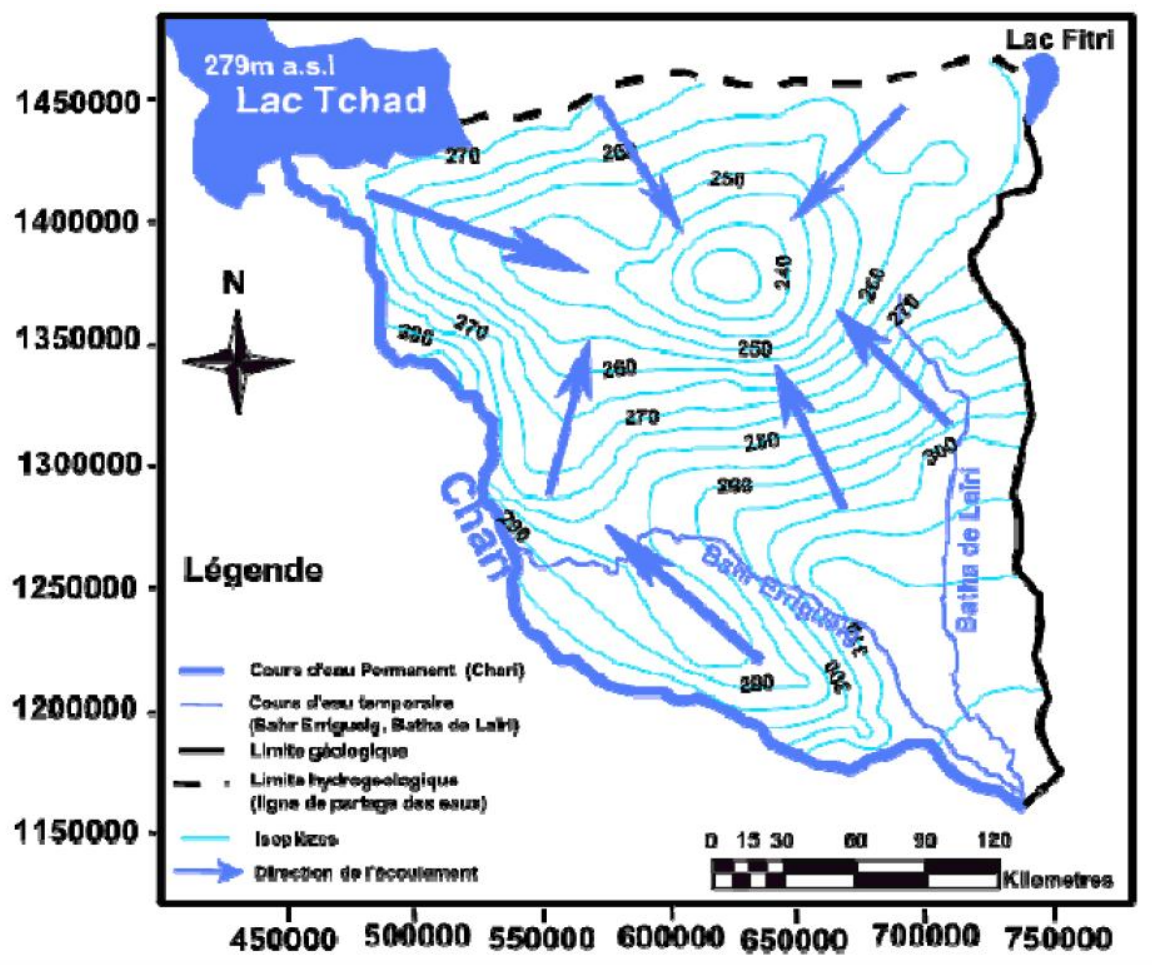

Fig.3 Chemical facies

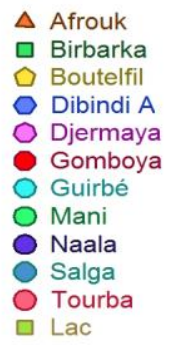

$\triangle$ Afrouk
Birbarka

$\checkmark$ Boutelfil

Dibindi A

Djermaya

Mani

Naala

Tourba

$\square$ Lac

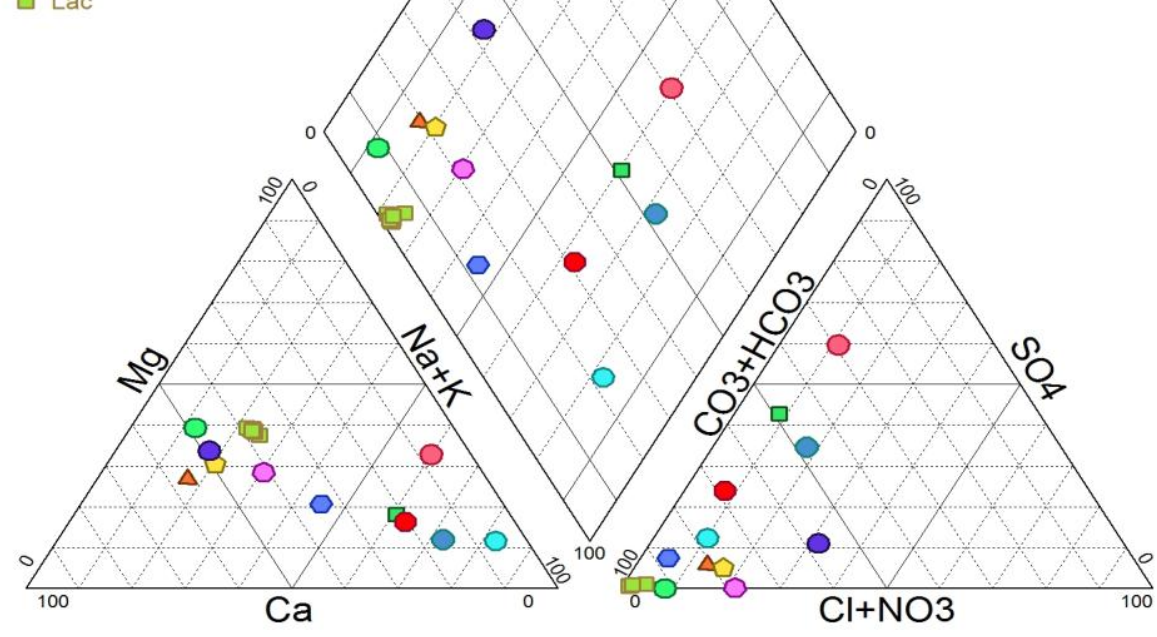


Fig.4 Spatial distribution of chlorides (left figure 4a) and sulphates (right figure 4b)

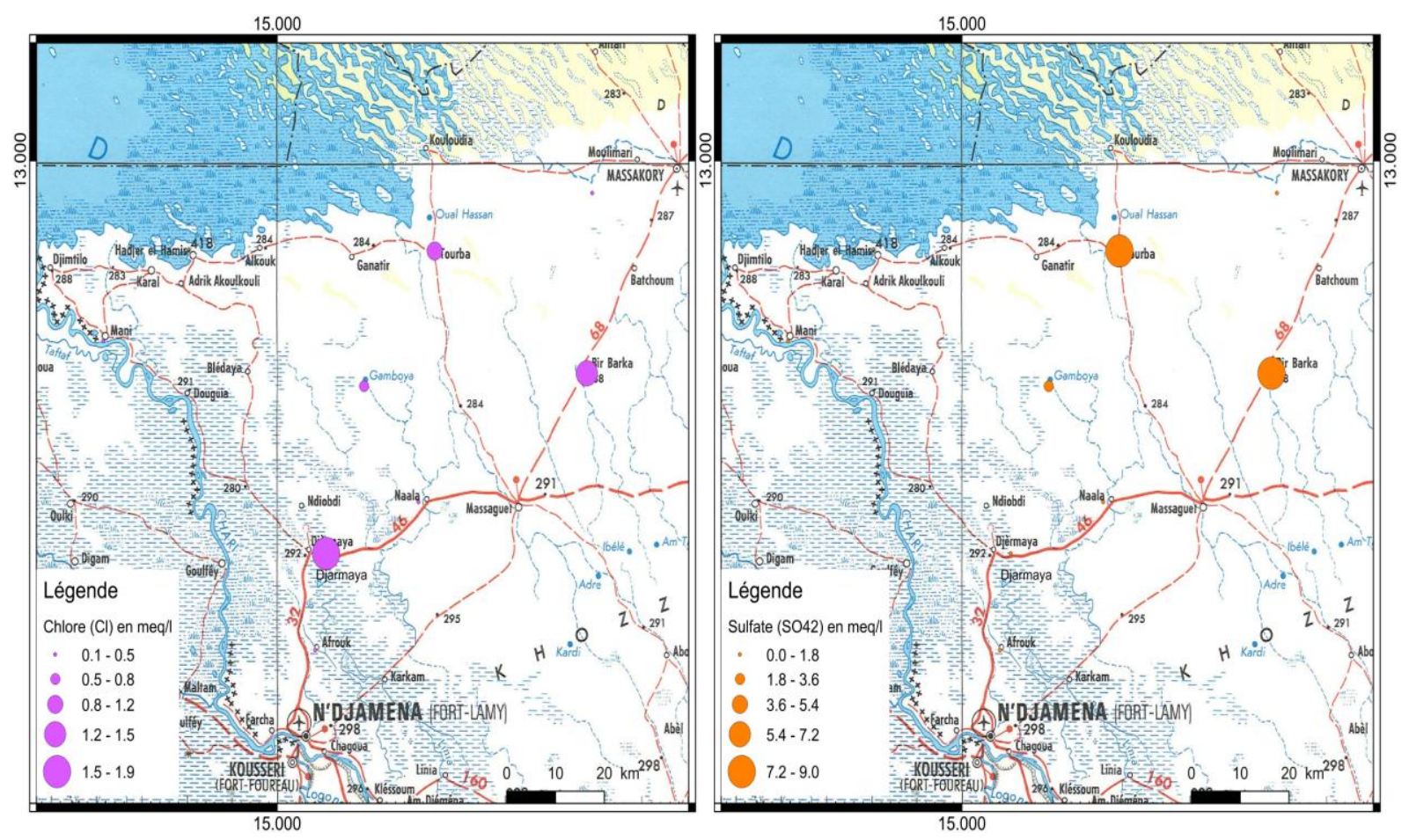

Fig.5 Evolution of $\mathrm{Ca}^{2+}$ vs $\mathrm{HCO}_{3}{ }^{-}$groundwater

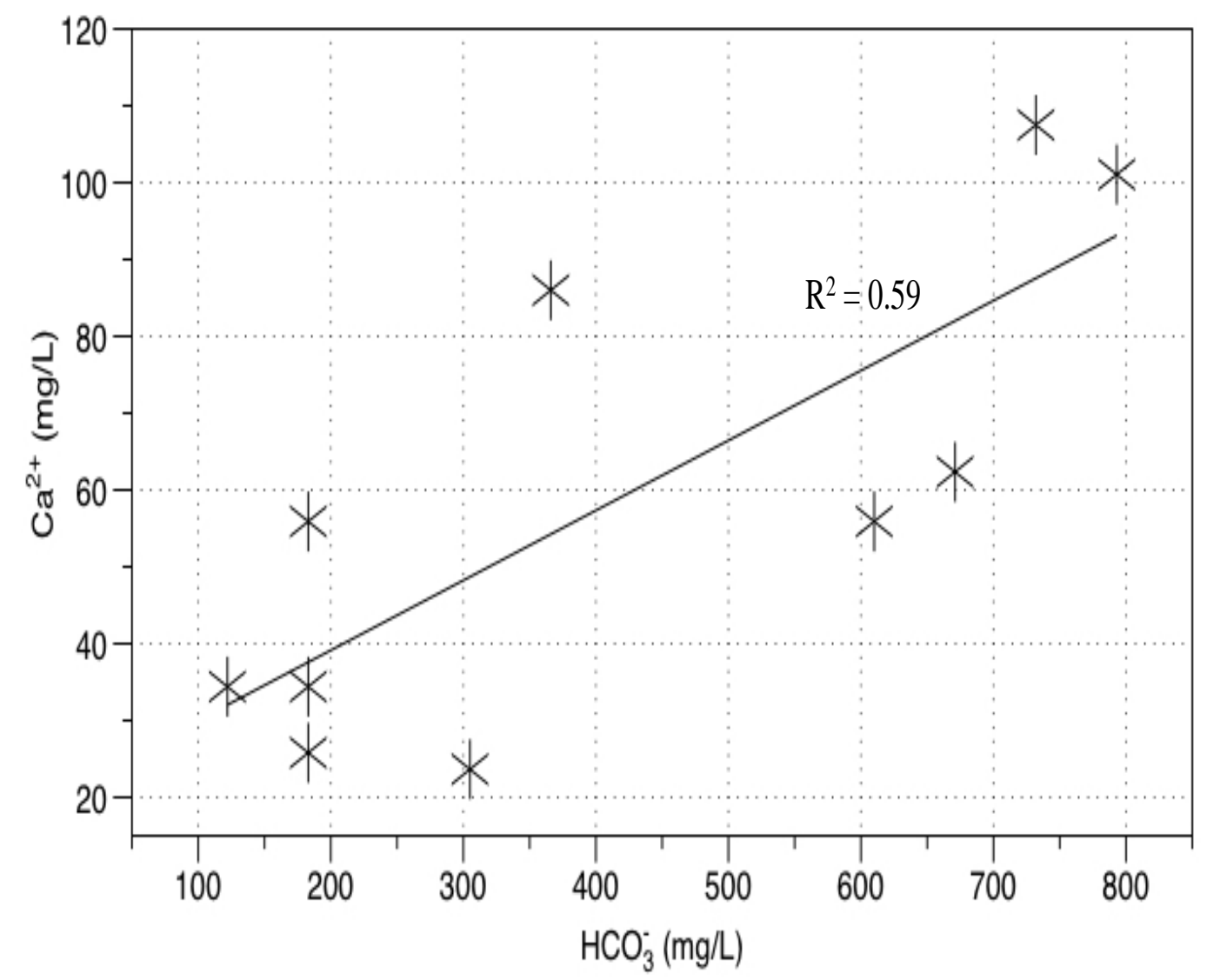


Fig.6 Evolution of $\mathrm{Ca}^{2+}$ vs $\mathrm{SO}_{4}{ }^{2-}$ groundwater and calcium sulfate dilution line

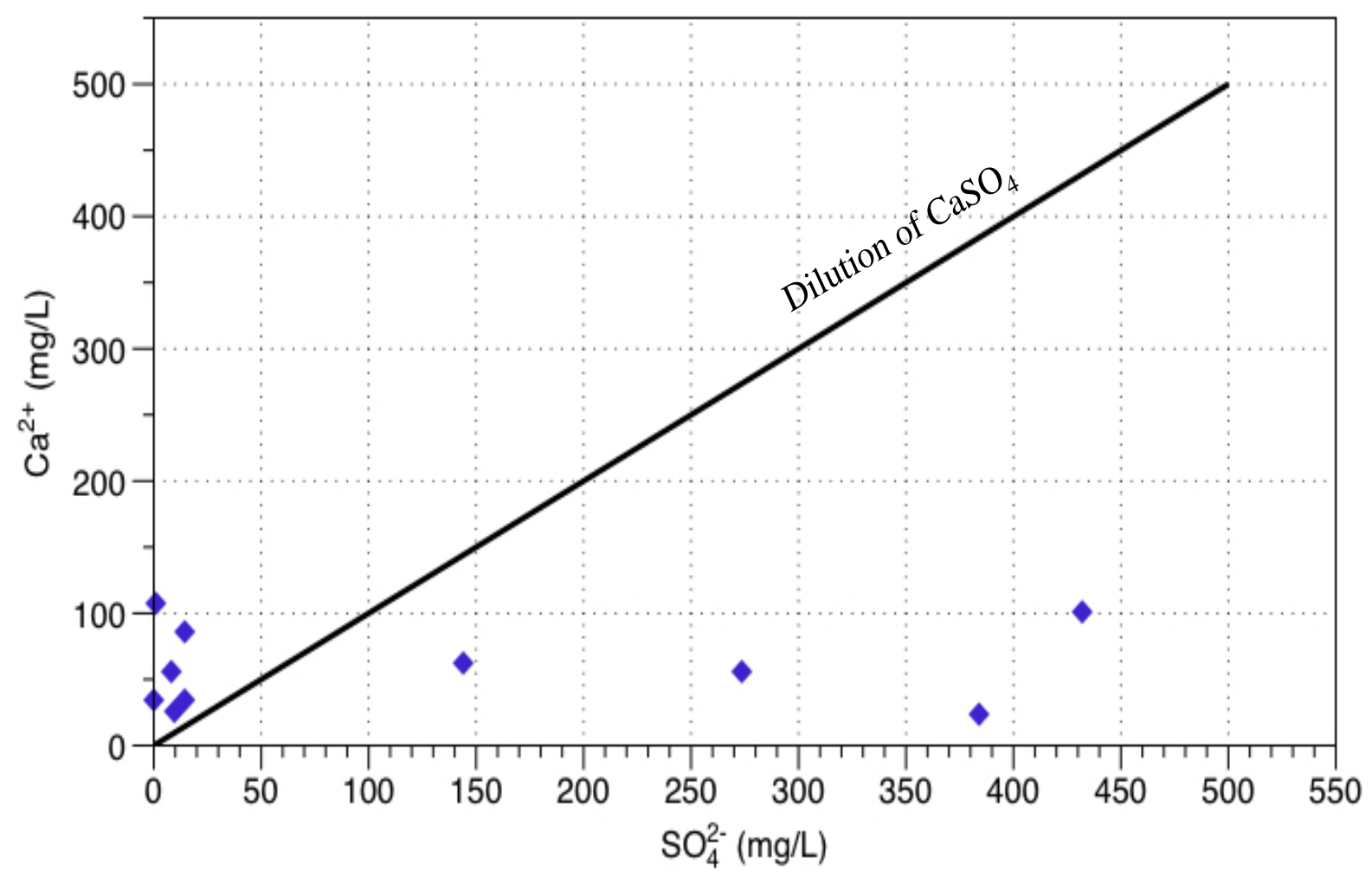

Fig.7 Evolution of $\mathrm{Na}^{+}$vs $\mathrm{HCO}_{3^{-}}$groundwater

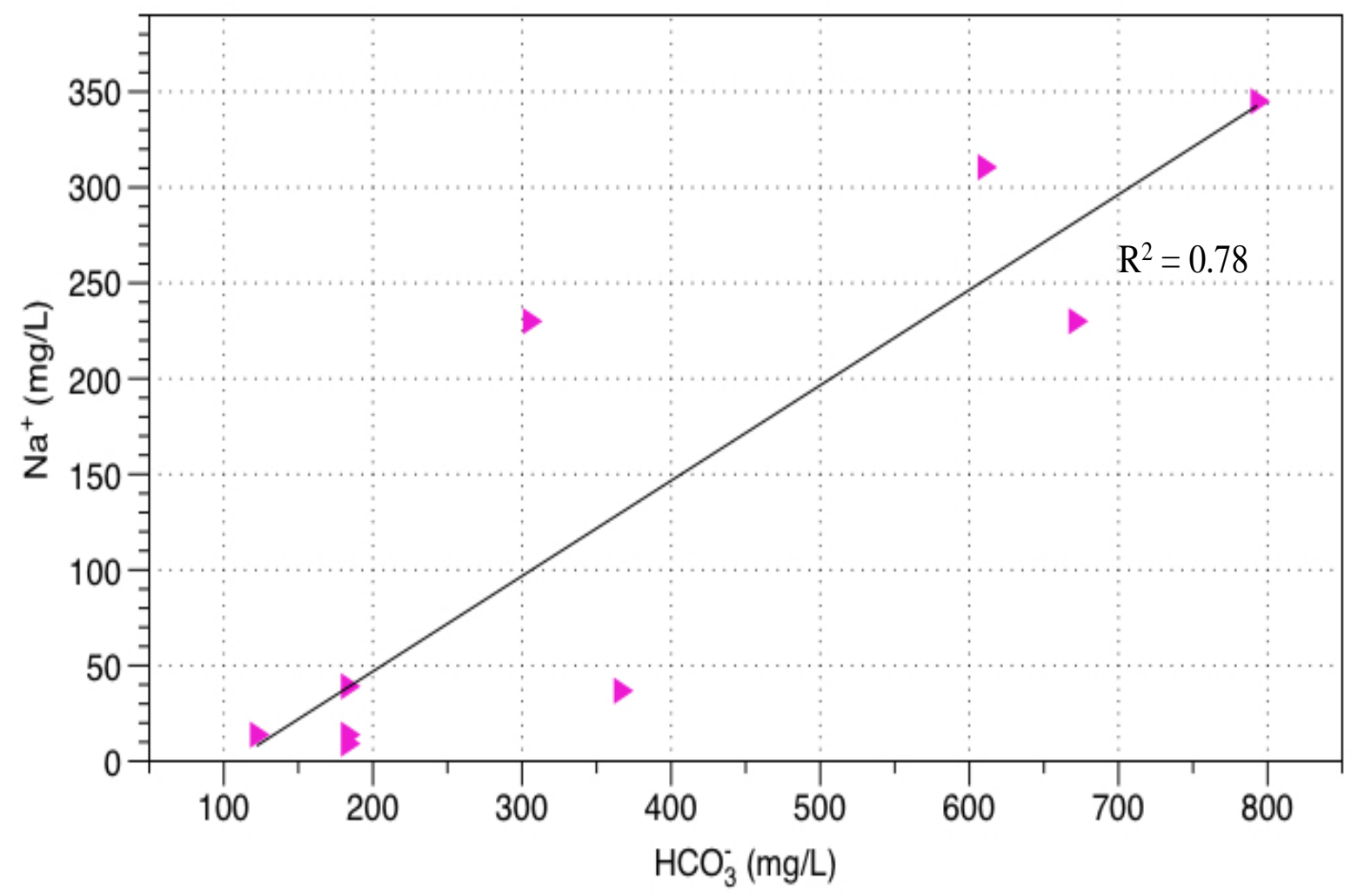


Fig.8 Evolution of $\mathrm{Na}^{+}$vs $\mathrm{Cl}^{-}$groundwater, Lake water, dilution straight Halite and the right of Composition of seawater

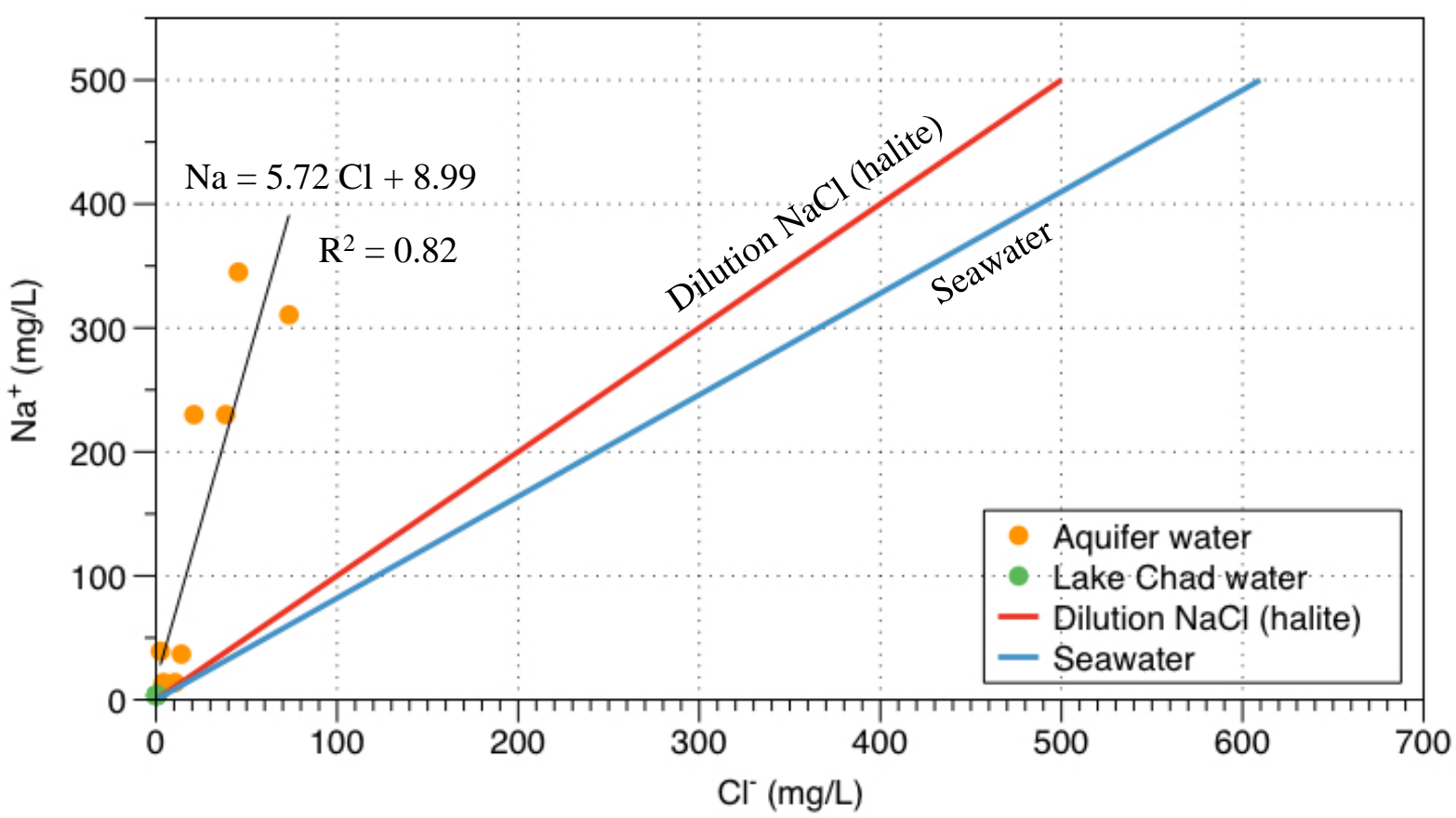

The aquifer extends over an area of $500000 \mathrm{~km}$ and is characterized by the presence of domes in the dune systems of Kanem and Harr in Chad and 3 piezometric depressions around Lake Chad (Eberschweiler, 1996; Leblanc, 2002). The hollow aquifers have an average amplitude of $40 \mathrm{~m}$, the most important of which are located in Bornou (Nigeria), Yaéré in Cameroon and in Chari-Baguirmi plain (Chad). These hydrodynamic abnormalities were recognized on the entire Sahel and have been the subject of several theories about their formations (Durand, 1982; Dieng et al., 1990; Ndiaye et al., 1993; Njitchoua and Ngounou Ngatcha, 1997; Djoret, 2000; Abderamane, 2012; Camille, 2015).

In the sector of Chari Baguirmi, Abderamane's piezometric map (Figure 2) shows a variability of the isopièzes curves. There are tight and spaced curves. The tight curves indicate that the flow is low, whereas the spaced curves show high hydraulic gradients.

This map also shows the waters flowing towards the depression of Chari Baguirmi in Kouka. This sense of flow is imposed by the perched position of Lake Chad in the west, relative to the depression, by the dome of Harr in the north, Chari - Logone rivers in the southwest and the Guera massif in the south East (Djoret, 2000; Massuel, 2001; Abderamane 2012).

\section{Physicochemical parameters}

The spatial distribution of sampling points shows a heterogeneity of the physico-chemical parameters of the study area. This heterogeneity is demonstrated on the entire web from Niger and Nigeria by Zairi (2008) and depression Chari Baguirmi (Chad) by Abderamane (2012).

The average groundwater temperature is $28.91{ }^{\circ} \mathrm{C}$. The spatial distribution of temperatures shows that the highest values are measured in Naala and Bir Barka wells and the lowest in Tourba. These water temperature values could be dependent on the ambient air temperature. It is also correlated (for some well) with the depth. So we could also think about the influence of geothermal energy.

The $\mathrm{pH}$ is a physicochemical parameter which varies in the study area. The different $\mathrm{pH}$ values obtained range between 6.88 and 8.10 with the majority of the values close to neutrality. This small variation may be due to contact between atmospheric $\mathrm{CO}_{2}$ and water open pits.

The spatial variation of the conductivity is also very important. In the study area, electrical conductivity shows an increasing evolution of Lake Chad towards 
depression and also a very important heterogeneity. The increase of the conductivity in the direction of the flow of water would be due on the one hand, to the phenomenon of evaporation which is linked to the weak hydraulic gradients and on the other hand, to the dissolution of the minerals in the water (Abderamane, 2012).

\section{Process of groundwater mineralization}

\section{Identification of geochemical processes by the binary diagram}

To characterize the geochemical processes responsible for the chemical variations that have been observed in the diagram, we have used, in this paragraph, the binary diagrams of the following characteristic ratios (Figure 5, 6 and 7):

$\mathbf{C a}^{2+} \mathbf{v s} \mathbf{H C O}_{3}{ }^{2-}$ : The graph of this pair shows a poor correlation $\left(\mathrm{R}^{2}=0.59\right)$ between $\mathrm{Ca}^{2+}$ and $\mathrm{HCO}_{3}{ }^{-}$This suggests that the hypothesis of the dissolution of calcite is ruled out.

$\mathrm{Ca}^{2+}{ }^{2+} \mathrm{SO}_{4}{ }^{2-}$ : Analysis Figure 4 shows the greater part of the samples deviate from the right dilution of calcium sulfate (gypsum).The hypothesis of the dissolution of gypsum is rejected.

$\mathrm{Na}^{+} \mathbf{v s}\left(\mathrm{HCO}_{3}{ }^{-}\right)$: This diagram shows a fairly good correlation between $\mathrm{Na}$ and $\mathrm{HCO}_{3}^{-}$the carbonated pathway results in alkalinization associated with the neoplasms sodium (trona or sodium hydrobicarbonate hydrated "NaHCO ${ }_{3} 2 \mathrm{H}_{2} \mathrm{O}$ ", improperly called soda $\left." \mathrm{Na}_{2} \mathrm{CO}_{3}, 10 \mathrm{H}_{2} \mathrm{O} "\right)$.

The $\mathrm{Ca}^{2+}$ could come from rainfall and concentrated by evaporation effect due to low hydraulic gradient during the transit of water in underground aquifer layers although it could also come by the dissolution of silicate rocks (granite arenas or clays). The contribution of $\mathrm{HCO}_{3}$ is due to the meteoric infiltration. The higher sulphate concentrations are not due to the dissolution of calcium sulphate. Sulphates can come from oxidation of pyritic nodules or meteoric waters and concentrated by evaporation.

\section{Origin of chlorine in groundwater}

The chloride ion is an ideal tracer to highlight the dissolution of salts and chlorinated evaporation (Cook and Herczeg, 2000). The origins of such a geochemical organization are diverse. It could result from a variability over time of chloride concentrations of the recharge poles of the free water, or even precipitation; of mineralization processes in the reservoir: by the dissolution of sodium chloride minerals (halite: $\mathrm{NaCl}$ or sylvite: $\mathrm{KCl}$ ). It may also have an origin by the use of chloride rich amendment used in Lake Chad polder (Carmouze et al., 1975). According to sedimentary descriptions, it was never mentioned to the presence of chlorinated salts within the Quaternary reservoir (PNUDFAO-CBLT, 1973). However, salts have been described on the surface near Lake Chad (Carmouze et al., 1975). It can therefore be assumed that they have been deposited by wind in the region and that they may represent a potential source of chlorides to the free water.

$\mathrm{Na}^{+}$vs diagram $\mathrm{Cl}^{-}$(Figure 8) shows a good correlation $\left(\mathrm{R}^{2}=0.82\right)$. But all points are placed above the dilution lines of halite and seawater (excess $\mathrm{Na}^{+}$). The slightly higher concentrations of $\mathrm{Na}^{+}$observed in the waters are not due to the dissolution of the halite. The high concentration of $\mathrm{Cl}$ could certainly be linked to an anthropogenic contribution either by an evaporation effect. These results confirm the absence of evaportitic rocks in the basin.

\section{Evaporation from Lake Chad and infiltration to the water table}

The $\mathrm{Na}^{+} \mathrm{vs} \mathrm{Cl}^{-}$groundwater is higher than surface waters (Figure 8). The ion ratios vis-à-vis $\mathrm{Cl}^{-}$and $\mathrm{Na}^{+}$Lake Chad are not kept during their transit through the unconfined aquifer where water rock interaction processes are changing concentrations. These chemical results confirm the existence of the evaporation of water during the transfer of water from the lake to the free aquifer but this phenomenon could be modified by other chemical processes (rock water interaction, substitution...).

The objective of this work is to know the characteristics and the functioning of the Haraz Al Biar aquifer system associated with Lake Chad with a view to sustainable management. Several sources of data contribute to the understanding of Haraz Al Biar aquifer. The hydrodynamic study made it possible to understand the evolution of the hydraulic gradient converges towards the Kouka depression. This sense of flow is imposed by the perched position of Lake Chad in the west, relative to the depression, by the dome of Harr in the north, the Chari - Logone River in the southwest and the Guera massif in the south. East. The water table is recharged not only by Lake Chad but also by other rivers like Chari 
and Logone. There is also an increase in the saline load of some wells in the study area. This increase is due to evaporation.

The piper diagram made it possible to have a more precise distribution of the different chemical facies of the aquifer waters. The different types of facies are more or less magnesian bicarbonate calcium facies, sodium bicarbonate potassium and facies sulfated sodium.

In the context of Haraz Al Biar aquifer in North Chari Baguirmi, several phenomena can contribute to the mineralization of waters. The water table is limited to the south by the city of N'Djamena, to the west by Chari Logone Rivers, in the center by Djermaya oil refinery, to the northwest by Lake Chad and to the north-east by the dunes from Harr. The mineralization of a water will depend also on the surface environment and the nature of the rocks crossed or in which it is stored, the residence time and the chemical controls.

The analysis of the chemical data made it possible to distinguish two charging poles. The mineralized waters come either from the dissolution of the minerals contained in the matrix of the rocks housing the aquifer or by the phenomenon of the evaporation of water.

\section{References}

Abderamane, H., 2012. Etude du fonctionnement hydrogéochimique du système aquifère du Chari Baguirmi. Thèse document de 277p.

Abderamane, H., Razack, M., and Vassolo, S., 2012. Hydrogeochemical and isotopic characterization of the groundwater in the Chari-Baguirmi depression, Republic of Chad, Environ. Earth Sci., 69, 23372350

Bensaâd, A., 2011. L'eau et ses enjeux au Sahara

Bouchez, C., 2015. Bilan et dynamique des interactions rivières-lac(s)-aquifères dans le bassin hydrologique du lac Tchad: Approche couplée géochimie et modélisation des transferts. Thèse univ-AixMarseille. 291p

BRGM, 1987. Actualisation des connaissances sur les ressources en eau de la République du Tchad. Deuxième partie: Synthèse des données hydrogéologiques et carte à 1/ 500 000, 116p.

Carmouze, J.P., Cheverry, C., Gac, J.Y., Maglione, G. and Roche, M. A., 1975. Aspects sédimentologiques actuels d'un bassin continental endoréique: le bassin tchadien. 9 pp. IX Congrès international de sédimentologie, Nice. 1975.
Cesar, J., 1990. Mission d'appui au programme ADER, volet restauration des pâturages au Laboratoire de farcha, CIRA-EMVT, Ndjamena, $34 \mathrm{p}$.

Cook, P.G. and Herczeg, A.L., 2000. Environmental tracers in subsurface hydrology. Boston/Dordrecht/London: Kluwer Academic Publishers. 529 pp.

Daïra, D., 2000. Etude de la recharge de la nappe du Chari Baguirmi par les méthodes chimiques et isotopiques. These document de 161p.

Dieng, B., Ledoux, E., and Marsily, G., 1990. Palaeohydrogeology of the Senegal sedimentary basin: a tentative explanation of the piezometric depressions.

Durant, M., 1982. Oscillations of the Lake Chad over the past 50,000 years: new data and new hypothesis.

Eberschweiler, C., 1996. Contexte géologique et hydrogéologique.in Livestock atlas of the Lake Chad basin.

Gac, J. Y., 1980. Géochimie du Bassin du Lac Tchad, Bilan de l'altération, de la l'érosion et de la sédimentation.

Joly, F., 2006. Les eaux sauvages des régions arides. Notions de base sur l'hydrologie des déserts

Kawtar, F.B., Mohammed, I., Sanae, F.B. and Abdellatif, T., 2004. Problèmes de dégradation de l'environnement par la désertification et la déforestation: impact du phénomène au maroc.

Leblanc, M., 2002. Use of GIS and remote sensing for water resources management of large semi-arid regions. A case study of the lake Chad Basin, Africa. Thesis, University of Glamorgan and Poitier University.220 p.

Louis, P., 1970. Contribution géophysique à la connaissance géologique du bassin du lac Tchad.

Margat, J., UNESCO and BRGM, 2008: Exploitations et utilisations des eaux souterraines dans le monde, $52 \mathrm{p}$,

Massuel, S., 2001. Modélisation hydrodynamique de la nappe phréatique quaternaire du bassin du lac Tchad-IRD 2001. Mémoire DEA. Université d'Avignon et des pays du Vaucluse, 85p.

Merem-Farah, H., 2017. Renouveau d'un système irrigué communautaire suite au déverrouillage de l'accès aux eaux souterraines profondes. Cas du territoire oasien de Sidi Okba dans le Sahara algérien

Ndiaye, A. \& Ndiaye, P., 2013. Climate Change, Environmental Degradation and the Quest for the usage of Natural Resources: Miracle or Mirage?

Ndiaye, B., Aranyossy, J.F. and Faye, A., 1993. Le rôle de l'évaporation dans la formation des dépressions en Afrique sahélienne: hypothèse et modélisation. 
Njitchoua, R. and Ngounou Ngatcha, B., 1997. Hydrogeochemestry and environmental isotope investigations of the north Diamare plain, northern Cameroon. Journal of African Earth Sciences, 25, 307-316.

Olivier, P., 2004. La surexploitation des eaux souterraines: enjeux et gouvernance

Pias, J., 1964. Les sols du Tchad. Retrieved from http://horizon.documentation.ird.fr/exl-

doc/pleins_textes/pleins_textes_5/b_fdi_10 11/13512.pdf

Pias, J., 1968. Contribution à l'étude des formations sédimentaires tertiaires et quaternaires de la cuvette tchadienne et des sols qui en dérivent (République $\mathrm{du}$ Tchad). Retrieved from http://horizon.documentation.ird.fr/exldoc/pleins_textes/cahiers/PTP/18537.

Pias, J., 1970. Les formations sédimentaires tertiaires et quaternaires de la cuvette tchadienne et les sols qui en dérivent.

PNUD-FAO-CBLT., 1973. Etude des ressources en eau du bassin du lac Tchad en vue d'un programme de développement. Tome I. Hydrogéologie, rapport technique FAO.

Schneider, J.L and Bonnet, M., 1968. Fluctuation des nappes du Kanem, Chari Baguirmi et Batha: programme 1964-1966. Vol1 à2; 64p.

How to cite this article:

Mahamat Nour A., H. Abderamane, B. Ngounou Ngatcha, P. Deschamps and Bouchezc. 2017. Characterization and Aquifer Functioning System of Haraz Al Biar (North Chari Baguirmi). Int.J.Curr.Res.Aca.Rev. 5(12), 52-64. doi: $\underline{\text { https://doi.org/10.20546/ijcrar.2017.512.008 }}$
Schneider, J.L., 2001. Géologie. Archéologie. Hydrogéologie de la République du Tchad. Mem. 1100 p., vol 2. Carte de valorisation des eaux souterraines de la République du Tchad, 1/1 500 000, Direction de l'Hydraulique, N'Djamena.

Schneider, J.L., and Wolff J.P., 1992. Carte géologique et Carte hydrogéologique au 1/1 500000 de la République du Tchad. Mémoire explicatif. Document BRGM N ${ }^{\circ} 209$, vol. 1 et 2, 689p.

Schroeter, P., Gear, D., 1973. Etude des ressources en eau du bassin du Lac Tchad en vue d'un programme de développement. Ressources en eau souterraines dans le bassin du Lac Tchad. Tome 1: Etude Hydrogéologique. PNUD/FAO, Rome.

SFDI (Société Française pour le Droit international), 2011. Quelle coopération régionale sur les eaux souterraines transfrontalières? Quelques réflexions concernant un processus en développement.

Sylvie, V. C., 2001. Gestion de l'eau et bassin versant De l'évidente simplicité d'un découpage naturel à son complexe mis en pratique.

Zaïri, R., 2008. Etude géochimique et hydrodynamique de la nappe libre du Bassin du Lac Tchad dans les régions du Diffa (Niger oriental) et du Bornou (nord-est du Nigéria). Thèse univ-Montpelliers II. $209 \mathrm{p}$ 